\title{
The role of ear mites of the genus Raillietia (Acari: Raillietiidae) in otitis of domestic ruminants ${ }^{1}$
}

\author{
Fernando R.A. Ferry² ${ }^{2}$, João L.H. Faccini ${ }^{3}$ and Tetsuo Inada ${ }^{4}$
}

\begin{abstract}
Ferry F.R.A., Faccini J.L.H. \& Inada T. 2011. The role of ear mites of the genus Raillietia (Acari: Raillietiidae) in otitis of domestic ruminants. Pesquisa Veterinária Brasileira 31(11):981-984. Departamento de Medicina Geral, Universidade Federal do Estado do Rio de Janeiro, EMC/CCBS, Hospital Universitário Gaffrée e Guinle, Rua Mariz e Barros 775, Tijuca, Rio de Janeiro, RJ 20270-004, Brazil. E-mail: fernandoferry@hotmail.com

This paper presents a hypothesis on the involvement of species of the genus Raillietia Trouessart in the pathology of parasitic otitis in domestic ruminants. The chelicerae and claws of the tarsi are structures that contribute significantly towards producing primary lesions. The movable digits of the chelicerae accidentally injure the epithelium that lines the ear canal, while the claws of the tarsi perforate the epithelium, allowing the mites to affix themselves while feeding. The lesions in the epithelium caused by the chelicerae and the claws favor multiplication of the bacteria that inhabit the ear canal, resulting in typical cases of otitis.
\end{abstract}

INDEX TERMS: Raillietia, otitis, domestic ruminants.

RESUMO.- [0 papel dos ácaros do gênero Raillietia (Acari: Raillietiidae) na otite de ruminantes domésticos.] Neste trabalho apresentamos uma hipótese para explicar o envolvimento dos ácaros do gênero Raillietia na patogênese da otite parasitária em ruminantes domésticos. As quelíceras e unhas dos tarsos são estruturas que contribuem significativamente para produzir as lesões primárias no epitélio. Os dígitos móveis das quelíceras acidentalmente causam injúria no epitélio que reveste o canal auditivo, enquanto as unhas dos tarsos perfuram o epitélio para permitir a fixação dos ácaros durante sua alimentação. As lesões no epitélio causadas pelas quelíceras e unhas dos tarsos favorecem a multiplicação das bactérias que habitam o canal auditivo, resultando em casos típicos de otite.

TERMOS DE INDEXAÇÃO: Raillietia, otite, ruminantes domésticos.

\footnotetext{
${ }^{1}$ Received on July 2, 2011.

Accepted for publication on August 18, 2011.

${ }^{2}$ Departamento de Medicina Geral, EMC/CCBS, Universidade Federal do Estado do Rio de Janeiro (UNIRIO), Hospital Universitário Gaffrée e Guinle, Rua Mariz e Barros 775, Tijuca, Rio de Janeiro, RJ 20270-004, Brazil. "Corresponding author: fernandoferry@hotmail.com

${ }^{3}$ Departamento de Parasitologia Animal, Instituto de Veterinária, Universidade Federal Rural do Rio de Janeiro (UFRRJ), Seropédica, RJ 23890000, Brazil. Fellow of CNPq. E-mail: faccinijlh@globo.com

${ }^{4}$ Departamento de Biologia Animal, Instituto de Biologia, UFRRJ, BR 465 Km 7, Seropédica, RJ 23890-000, Brazil.
}

\section{INTRODUCTION}

Mites of the genus Raillietia Trouessart, 1902 are parasites that inhabit the external ear canal and the external surface of the tympanic membrane of domestic and wild ruminants. Three species of Raillietia have been described in Brazil: R. auris, $R$. flechtmanni and $R$. caprae. The first was diagnosed only in cattle, the second in buffaloes and cattle, and the third exclusively in goats (Faccini et al. 1992a, Faccini \& Ribeiro 2008).

Perforation of the tympanum, resulting in vestibular disease, redness, ulceration and hemorrhage of the tissue that lines the ear canal, blockage of the ear canal by plugs of paste-like wax, ataxia (due to rupture of the tympanic membrane and lesions to the vestibular system), anorexia, restlessness, unilateral facial paralysis, debilitation, hearing loss and head shaking have all been reported in association with ear mite infestations [see Krametter-Froetscher (2006) for early literature citation]. Most of these clinicopathological signs have also been reported in cattle infested with Raillietia spp. in Brazil, predominantly in breeds of Zebu (Nunes et al. 1980, Leite et al. 1989b).

The association between Raillietia spp. and bacteria (Leite et al. 1987) and that between Malassezia spp. (Duarte et al. 1999) and rhabditiform nematodes (Duarte et al. 2001) have been reported in cases of bovine otitis in Brazil. The association between Mycoplasma spp. and Raillietia caprae in goats has been reported in Australia (Cottew \& 
Yeats 1982), in the United States (DaMassa 1983), in Brazil (Ribeiro et al. 1995) and in Mexico (Otero et al. 2009), while Mycoplasma spp. and Raillietia auris and R. flechtmanni have also been found in cattle in Brazil [unpublished doctoral thesis (Santos 2009).

The objective of this paper was to present a hypothesis on the probable mechanisms involved in the feeding and affixation of species of the genus Raillietia and their association with the pathology of otitis in domestic ruminants. The morphology of $R$. flechtmanni and the association between Raillietia spp. and cattle were used as a model.

\section{MATERIALS AND METHODS}

The specimens of Raillietia flechtmanni used in this study were obtained from the external ear canal of cattle slaughtered at the Santa Cruz industrial slaughterhouse (no longer in business) in the city of Rio de Janeiro, Brazil, in accordance with the method established by Leite et al. (1989a), which, in brief, consists of flushing the ears of the cattle with $100 \mathrm{ml}$ of water injected under pressure into the ear canal immediately following slaughter. The mites collected were stored in closed jars, transported to the laboratory and submitted to preparation for scanning electron microscopy (SEM) in accordance with the method described by Ferry et al. (1994). The following sequence was carried out: first the mites were cleaned, fixed in glutaraldehyde and cleaned in ultrasound; then post-fixed with osmium tetroxide, dehydrated in a series of alcohol, dried at the critical point in liquid CO2, mounted on aluminum supports using double-sided adhesive tape, metalized with gold and analyzed, after which SEM micrographies were produced.
For examination of the infested external ear canal, the material was prepared as described by Nunes \& Nunes (1975), consisting initially of fixation in formaldehyde $10 \%$ and decalcification in nitric acid 5\% for 47 days. After that, the material was embedded in paraffin, microtomed and stained with hematoxylin and eosin.

\section{RESULTS}

The morphological examination of the structures involved in the feeding process (chelicerae: Fig.1A,B) and fixation (tarsi: Fig.1C,D) of Raillietia flechtmanni permits a hypothesis to be made on how the process of mechanical injury to the epithelium of the host's ear canal may develop. The third segment of the chelicerae (Fig.1B) is composed of the movable digit, which is positioned ventrally, and the fixed digit, which is positioned dorsally. The movable digit is scythe-shaped, is articulated with the second segment at its basal portion and has three fang-like projections in the distal portion (arrow). The morphology of the movable digit suggests an adaptation for perforating and cutting the epithelium of the ear canal as shown in Figures 2A and 2B. With respect to the tarsus (Fig.1C,D), the final segment of the leg of the mites, the presence of two claws are seen in R. flechtmanni (arrow). These structures are present on the eight legs of species of Raillietia. Figure 2C suggests that the claws may be used by the parasite to cling to the epithelium of the ear canal while feeding.

\section{DISCUSSION AND CONCLUSION}

Although the chelicerae of Raillietia spp. are adapted to perforate and cut the epithelium, the species included in
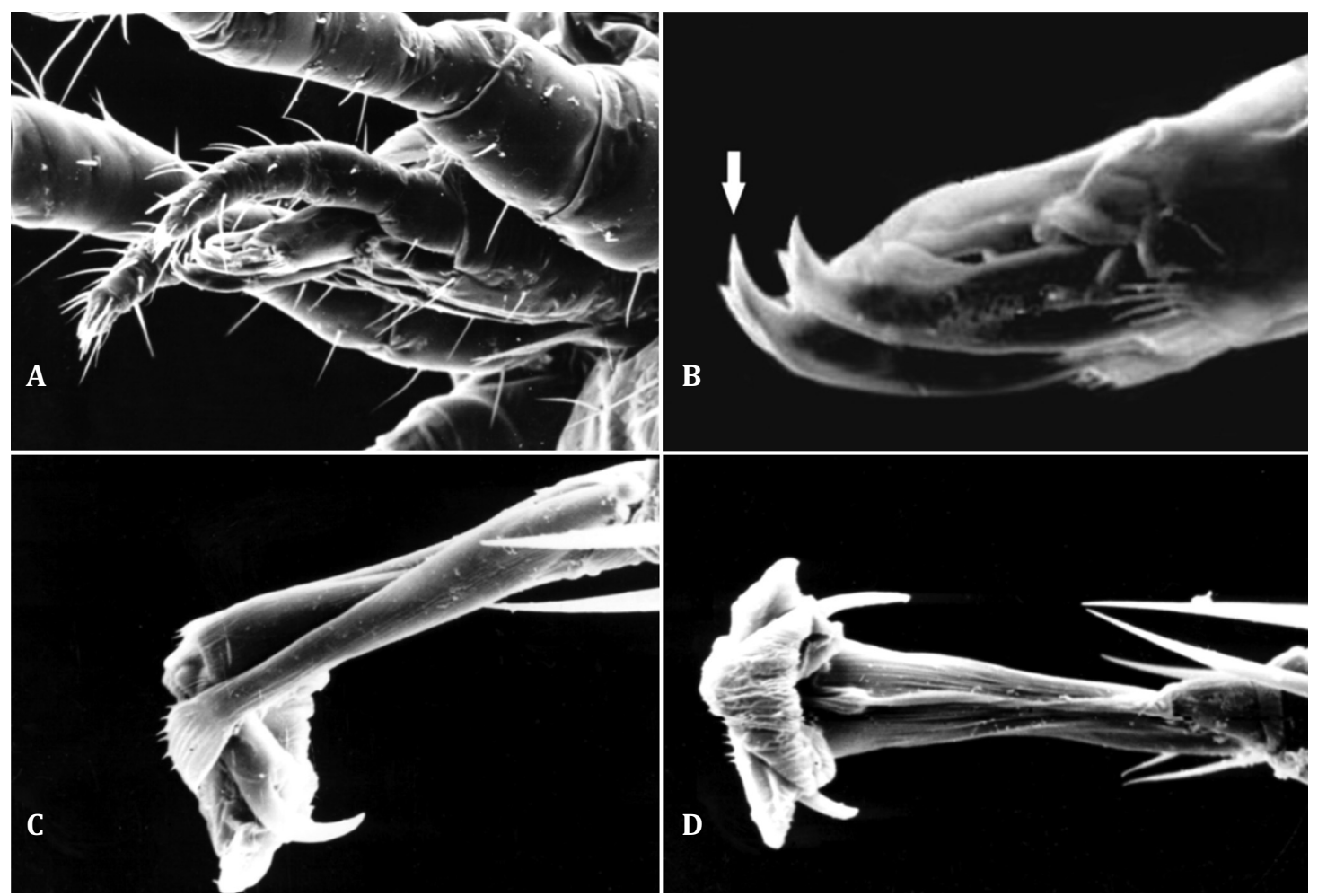

Fig.1 (A) Lateral view of the gnathosoma of a female of Raillietia flechtmanni, showing the chelicerae (arrow). (B) Figure 1 shows the left chelicerae in greater detail. The mobile digit is shaped like a scythe when seen from the side and has three pointed projections (arrow). (C) Extremity of the tarsus of a female of Raillietia flechtmanni, viewed from the side, showing the claw (arrow). (D) Extremity of the tarsus of a female of Raillietia flechtmanni, ventral view, showing the two claws (arrow). 

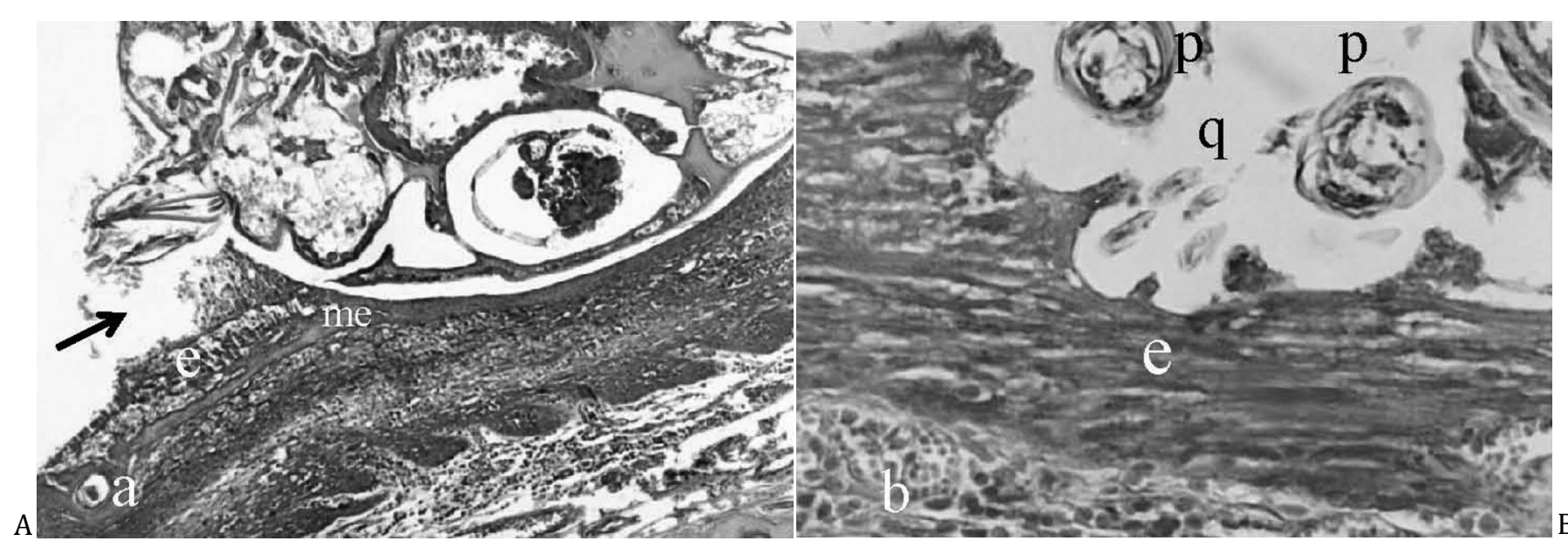

Fig.2 (A) Histological section of the external ear canal of a cow, showing a female of Raillietia sp. in a medial saggital section. The gnathosoma is shown on the left. The fixative fluid was probably used when the mite was feeding. The epithelium around the gnathosoma is shedding (arrow). The fibrin-like, eosinophilic material (me) can be seen on the slide containing the epithelial material, below and to the left of the mite, occupying a ridge formed in the shedding epithelium (e). A claw (a) can be seen to the left, embedded in the epithelial surface. A diffuse inflammatory infiltrate is visible over the entire epithelium. (B) Histological section of the external ear canal of a cow, showing Raillietia sp. in a cross section at the level of the gnathosoma. Note that the chelicerae (q) are in contact with the epithelium (e), which shows degenerated cells. Note the red blood cells inside the capillaries dilated by the inflammatory reaction. The eosinophilic material (me) that surrounds the mite is fibrin-

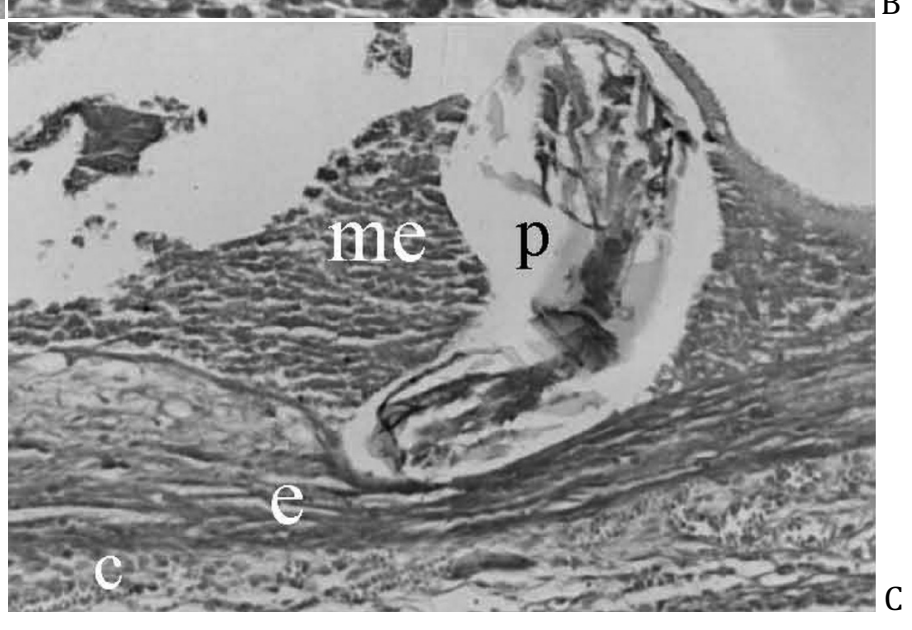
-like and purulent. Sensory palpi (p). (C) Histological section of the external ear canal of a cow, showing a tarsus of Raillietia sp. embedded in the epithelium and compressing it. The tarsus (p) is shown in the center of the image. Note the fibrin-like, purulent eosinophilic material (me) surrounding it. The lamina propria is hemorrhagic and thick. Epithelium (e). Figures are not to scale.

this genus apparently do not feed specifically on tissue or blood, since during the process of clarification and mounting of the mites for microscopic examination, only an amber-colored, cheese-like mass was found inside the mites, which was suggestive of earwax rather than tissue or blood from the host. Nevertheless, the complex structure of the gnathosoma of the mites of the genus Raillietia suggests that these mites may predigest food prior to ingesting it, which would justify the absence of host tissue inside the mites. Therefore, the type of food ingested by these mites still remains to be confirmed.

Feeding behavior in Mesostigmata mites ranges from generalized feeders such as Haemogamasus ambulans, which feeds on the fluid or dried blood of vertebrates, flea feces and living or dead arthropods (Furman 1958), to very specific feeders such as Dermanyssus gallinae, a blood-sucking mite. According to Furman (1958), generalized feeder mites rarely penetrate the skin of vertebrate hosts. With respect to the feeding habits of the ear mites of the genus Raillietia, the species may be included somewhere between the two extremes of Furman's classification. The species included in the genus Raillietia probably feed basically on earwax, microorganisms that live on the surface of the epithelium of the ear canal and residue from the shedding epithelium. Perforation of the epithelium that lines the external ear canal during the feeding process would be accidental albeit common, since the chelicerae are in direct contact with the epithelium (Figure 2A).

As in parasite infestations by Raillietia spp., the claws of the tarsi of some species of the Rhinonyssidae, nasal parasites of birds, are used by the mites to cling to the nasal epithelium, perforating and tearing the tissue of the nasal cavity of birds (Feider \& Mironescu 1972). The lesions caused in the epithelium of the ear canal and the tympanic membrane of cattle and other domestic ruminants are probably the result of the combined action of the chelicerae and the claws of the tarsi, the former involved directly in the feeding process, while the claws of the tarsi are used by the mites to affix themselves during feeding. The resultant injury to the epithelium that lines the ear canal and the tympanic membrane facilitates the infiltration and colonization of these areas by resident microorganisms, consequently evolving to otitis. Leite et al. (1987) reported having found 28 different types of bacteria in the auditory system of cattle infected by Raillietia auris, those of the genera Proteus and Pseudomonas being the most commonly found. Both these genera and also Corynebacterium pyogenes are always found in association with chronic inflammatory processes, whereas Duarte et al. (1999) presumptively identified 24 species of Malassezia, which consisted of M. globosa (12), 
M. slooffiae (5), M. furfur (5) and (2). Finally, the finding of various species of Mycoplasma inside R. caprae, R. auris and $R$. flechtmanni suggests the possibility that this species may be involved in the transmission of mycoplasmosis in goats, as documented in Australia (Cottew \& Yeats 1982), USA (DaMassa 1983), Brazil (Ribeiro et al. 1995) and Mexico (Otero et al. 2009). The hypothesis of a possible association between Mycoplasma spp. and species of Raillietia is feasible, since $R$. auris is a parasite commonly found in the ear canal of cattle (Faccini et al. 1992b) and furthermore Santos et al. (2009) recently found seven species of Mycoplasma in the ear canal of clinically normal cattle slaughtered for human consumption in Brazil.

Faccini et al. (1992b) reported a prevalence of Raillietia auris in Brazilian beef cattle of $85-100 \%$ and that the number of mites per animal may range from 1 to 146 . Since each mite has two chelicerae and eight tarsi (with two claws on each tarsus), making a total of 16 claws per mite, it is reasonable to speculate that the chelicerae and the tarsi constitute important structures in the pathogenesis of parasitic otitis associated with species of Raillietia. Further studies are necessary to investigate the probable effect of the enzymes present in the salivary secretion of mites as additional causes of injury to the epithelium of the ear canal in ruminants.

Both direct observations of the chelicerae and tarsal claws, and histological pictures of parasitism lead us to conclude that the lesions in the epithelium caused by species of Raillietia allow the colonization and multiplication of bacteria resulting in otitis.

Acknowledgements.- The authors are grateful to Dr. Vera Nunes Alvarenga for having supplied the histological slides of the external ear canal of cattle, and to Dr. Reinalda Marisa Lanfredi (deceased) for her help with the images taken from the scanning electron microscope.

\section{REFERENCES}

Cottew G.S. \& Yeats F.R. 1982. Mycoplasmas and mites in the ear of clinically normal goats. Aust. Vet. J. 59(3):77-81.

DaMassa A.J. 1983. Prevalence of mycoplasmas and mites in the external auditory meatus of goats. Calif. Vet. 37(10):10-13.

Duarte E.P., Melo M.M., Hahn R.C. \& Hamdan J.S. 1999. Prevalence of $M a-$ lassezia spp. in the ears of asymptomatic cattle and cattle with otitis in Brazil. Med. Mycol. 37(3):159-162.

Duarte E.R., Melo M.M. \& Hamdan J.S. 2001. Epidemiological aspects of bovine parasitic otitis caused by Rhabditis spp. and/or Raillietia spp. in the state of Minas Gerais, Brazil. Vet. Parasitol. 101(1):45-52.

Faccini J.L.H., Leite R.C. \& Costa A.L. 1992a. Description of Raillietia flecht- manni sp.n. (Acari: Gamasida). Mem. Inst. Oswaldo Cruz 87(Suppl.1): 95-96.

Faccini J.L.H., Fonseca A.H., Costa A.L. \& Leite R.C. 1992b. Distribuição geográfica e prevalência das espécies do gênero Raillietia Trouessart em bovinos no Brasil. Revta Bras. Parasitol. Vet. 1(2):109-110.

Faccini J.L.H. \& Ribeiro V. 2008. Raillietia caprae (Acari: Raillietiidae) and Psoroptes ovis (Acari: Psoroptidae) in the ears of goats in the state of Rio de Janeiro, Southeast Brazil. Revta Bras. Parasitol. Vet. 1(1):59-61.

Feider Z. \& Mironescu I. 1972. Une modalité particulière de perforer la muqueuse nasale, utilisée par les acariens de la famille Rhinonyssidae Trouessart, 1895. Acarologia 16(2):21-31.

Ferry F.R.A., Lanfredi R.M., Faria S.M., Inada T. \& Faccini J.L.H. 1994. Método de preparo de ácaros do gênero Raillietia Trouessart (Acari: Gamasida) para estudo ao microscópio eletrônico de varredura. Revta Bras. Parasitol. Vet. 3(1):65-68.

Furman D.P. 1959. Feeding habits of symbiotic mesostigmatid mites of mammals in relation to pathogen-vector potentials. Am. J. Trop. Med. Hyg. 8(1):5-12.

Krametter-Froetscher R., Leschnik M., Hoegler S., Loewenstein M. \& Baumgartner W. 2006. Occurrence of the ear-mite Raillietia auris in cattle in Austria. Vet. J. 171(1):186-188.

Leite R.C., Nunes V.A., Coelho A.M.B., Chiloff M.A.G. \& Nunes I.J. 1987. Patologia da infecção do conduto auditivo de bovinos por Raillietia auris (Leidy, 1872) Trouessart, 1902 (Acari: Mesostigmata). II. Achados bacterianos. Arq. Bras. Med. Vet. Zoot. 39(2):325-332.

Leite R.C., Faccini J.L.H. \& Costa A.L. 1989a. Avaliação de uma técnica in vivo para medir a infestação por ácaros do gênero Raillietia Trouessart, 1902 (Acari) em bovinos. Mem. Inst. Oswaldo Cruz 84(4):309-311.

Leite R.C., Nunes V.A., Faccini J.L.H., Lopes C.W.G., Nunes I.J. \& Costa A.C. 1989b. Aspectos clínicos da Raillietiose bovina. Arqs Univ. Fed. Rural Rio de Janeiro 12(1/2):83-91.

Nunes V.A. \& Nunes I.J. 1975. Técnica de exame post-mortem do sistema auditivo aplicada ao estudo de otites em bovinos. Arq. Esc. Vet. UFMG 27(2):155-161.

Nunes V.A., Nunes I.J., Santos M.N., Chiloff M.A.G. \& Silva J.M.L. 1980. Patologia da infecção do ouvido de bovinos por Railletia auris (Leidy, 1872) Trouessart, 1902 (Acari:Mesostigmata). Aspectos macroscópicos. Arq. Esc. Vet. UFMG 32(3):325-331.

Otero J.N., Jaramillo L.M., Miranda E.M.R., Navarro J.A.H. \& Quintero M.T.M. 2009. Association of Raillietia caprae with the presence of Mycoplasmas in the external ear canal of goats. Prev. Vet. Med. 92(1/2):150-153.

Ribeiro V.R., Nascimento E.R., Faccini J.L.H., Nascimento M.G.F. \& Lignon G.B. 1995. Presença de Micoplasmas em exemplares de Raillietia caprae coletados do conduto auditivo externo de caprinos. Revta Bras. Med. Vet. 17(1):122-124.

Santos S.B. 2009. Imunoperoxidase e métodos moleculares na detecção de Mycoplasma spp. (Mollicutes: Mycoplasmataceae) em conduto auditivo de bovinos e em Raillietia spp. (Gamasida: Raillietiidae). Tese de Doutorado, Universidade Federal Rural do Rio de Janeiro, Seropédica, RJ. 76p

Santos S.B., Nascimento E.R., Faccini J.L.H. \& Barreto M.L. 2009. Potentially pathogenic Mycoplasmas in the external ear canal of clinically normal cattle in southeast Brazil: First report. Braz. J. Microbiol. 40(3):455-457. 